\title{
7.2. Wizerunek Wojciecha Drewniaka w jego książkach Historia Bez Cenzury. Dyskursywna analiza cech wizerunkowych „pasjonat” oraz „ma dużą wiedzę historyczną” - Anna Barańska-Szmitko
}

https://doi.org/10.18778/8220-429-2.15

\subsubsection{Wprowadzenie}

Celem niniejszego tekstu jest określenie wizerunku Wojciecha Drewniaka, komunikowanego w jego tekstach z cyklu książek Historia Bez Cenzury oraz przede wszystkim ukazanie sposobów komunikowania w tych wypowiedziach cech wizerunkowych „pasjonat” oraz „ma dużą wiedzę”. Opis badania, analizy i wyników poprowadzony jest w taki sposób, by zobrazować scharakteryzowaną w poprzednim rozdziale metodę zastosowanej dyskursywnej analizy wizerunku na materiale empirycznym, dzięki której wymienione wyżej cele badawcze możliwe są do osiągnięcia w badaniu intersubiektywnym, bez uwzględniania intencji nadawczych, a ze skupieniem na efekcie wizerunkowym i sposobach jego konstruowania. Podkreślić jednak należy, że niniejszy rozdział powstawał w szczycie pandemii koronawirusa SARS-CoV-2, co znacznie utrudniło zebranie danych, a zgromadzenie satysfakcjonującej próby zostało całkowicie uniemożliwione. Dostępne kwestionariusze są ubogie liczbowo i użyto ich w celu zilustrowania omawianej metody, niestety ujęcie ilościowe nie może być traktowane jako miarodajne. Uzyskane dane zaznaczają pewne tendencje (i w taki sposób są opisywane), nie pozwalają jednak wnioskować o zauważonych zjawiskach jako pewnych, zwłaszcza gdy mowa o ich proporcjach.

Wizerunek autora książek popularnonaukowych nie wzbudzał do tej pory zainteresowania badaczy. Jak zaznaczono $\mathrm{w}$ poprzednim rozdziale, badania dotyczące image'u osób skupiają się raczej na wizerunku polityków, choć pojawiają się też badania związane z przedstawicielami kultury. Tak na przykład spośród opracowań wizerunków polityków wymienić należy analizę imageów takich osób jak: Jarosław Kaczyński (Brodnicka 2019), Ewa Kopacz, Beata Szydło, Donald Tusk (Gierło-Klimaszewska, Gajda 2019), Donald Trump (Rosińska 2019), Józef Stalin (Sarna 2019), Rafał Dudkiewicz (Adamczyk 2016), Leonid Kuczma (Mazurkiewicz 2008) czy ogólniejsze ujęcie wizerunku kobiety-polityka (Vashkecich 2018). Są też badania poświęcone w pełni lub częściowo wizerunkowi osób szeroko rozumianej kultury, jak np. reżyserowi i politykowi Grzegorzowi Braunowi (Kosman 2019), Teodorowi Parnickiemu (Stasiołek 2012), ks. Józefowi Tischnerowi (Secler 2013) czy Steve’owi Jobsowi (Szymański 2013).

Trudno też o badania dotyczące Wojciecha Drewniaka jako autora książek. W nielicznych pracach pojawia się jako youtuber - przedstawiciel stylu popular- 
nonaukowego (Maciejak 2018) lub jako historyk kształtujący pamięć zbiorową (Wójcik 2019). Analizie poddano też relację między reprezentowanym przez niego dyskursem popularnonaukowym na YouTube a jego wizerunkiem (Barańska-Szmitko 2020b) czy też skupiono się na jego image'u, ale również komunikowanym we wspomnianym medium (Barańska-Szmitko 2020a). Choć znaleźć można prace o wpływie szeroko rozumianego dyskursu i języka youtuberów na polszczyznę (np. Maciołek 2017; Stefan 2019; Gronkowska 2019; Nobis 2019), to nie poświęcano uwagi omawianemu tu historykowi ani jako vlogerowi, ani jako autorowi książek.

Tym bardziej nie badano też takich cech wizerunkowych jak „pasjonat” czy „ma dużą wiedzę historyczną”. Opracowanie analogicznej do ostatniej z tych cech, czyli analiza cechy „znawca tematu” znajduje się w opracowaniu Barańska-Szmitko (2018b), gdzie odtworzono wykładniki komunikacyjne właściwe czterem felietonistom (Krzysztofowi Vardze i Piotrowi Zarembie - piszącym o kulturze i Szymonowi Hołowni oraz Magdalenie Środzie - poruszającym tematy społeczno-polityczne).

Brak badań w zakresie wizerunku osoby popularyzującej naukę i w obrębie wybranych cech wizerunkowych przy jednoczesnej dużej popularności wspomnianego dyskursu i zataczającego coraz szersze kręgi zjawiska konwergencji mediów wydaje się uzasadniać podjęcie proponowanego tematu.

\subsubsection{Zaplecze teoretyczno-metodologiczne}

Wszystkie teoretyczno-metodologiczne zagadnienia zostały opisane w komplementarnym (poprzednim) rozdziale tej książki, nie będą więc tutaj powtarzane, a jedynie dla porządku zarysowane.

Zapleczem teoretycznym niniejszych badań jest racjonalny konstruktywizm Michaela Fleischera, w którym komunikacja stanowi mechanizm systemu społecznego i nie rozpatruje się jej w kategoriach typowych dla modeli transmisyjnych (nadawca-odbiorca) (Fleischer 2007: 174). Rozróżnia się wypowiedź (to, co zostało powiedziane, napisane) od komunikatu (konstrukt zbudowany przez odbiorcę na podstawie wypowiedzi) (Fleischer 2008: 60), a tym samym mówienie (artykułowanie wypowiedzi) od komunikowania (konstruowanie komunikatu przez odbiorcę na podstawie wypowiedzi) (Fleischer 2012: 13).

Postuluje się stosowanie metod empirycznych, pozwalających na intersubiektywną weryfikację założeń i ewentualną ich falsyfikację (Fleischer 2008: 53-56). W analizie nie uwzględnia się intencji nadawczych, poprawności bądź niepoprawności komunikacji, natomiast bada się efekt komunikacyjny (w przypadku opisywanego niżej badania - wizerunek) i funkcjonalne działania dyskursowe (tutaj: realizujące funkcję komunikowania cech wizerunkowych „pasjonat” oraz „ma dużą wiedzę historyczną”), uwzględniając zarówno aspekt jakościowy, jak i ilościowy (Fleischer 2008: 97-100). 
Sam wizerunek (image) rozumie się jako wyobrażenie, konstrukt na temat obiektu (kogoś lub czegoś), powstałe jako efekt kontaktu z wypowiedziami autorskimi (wizerunek osoby wypowiadającej się) lub wypowiedziami o danym obiekcie (Barańska-Szmitko 2018b: 37).

Wykorzystano dyskursywną analizę wizerunku na materiale empirycznym (zob. poprzedni rozdział). Respondenci przeczytali przedstawione im teksty, wskazali cechy, jakie na podstawie wypowiedzi przypisali autorowi. Wynotowali fragmenty, w których cechy „ma wiedzę” oraz „pasjonat” się aktualizują. Cytaty przyporządkowane tym cechom poddano analizie, by wyłonić właściwe im wykładniki komunikacyjne.

Cechy wizerunkowe to przypisane przez respondentów autorowi tekstu określenia, które skategoryzowano/skodowano właśnie w spójne cechy wizerunkowe (np. epitety takie jak ,zabawny”, „dowcipny”, „z poczuciem humoru” skategoryzowano jako cechę wizerunkową „zabawny”). Wykładniki komunikacyjne/ dyskursowe $^{14}$ rozumie się jako dyskursowe sposoby komunikowania konkretnych cech wizerunkowych, mogące się realizować w różnych aspektach dyskursu (np. leksyka, konstrukcja gramatyczna, ustalanie określonych relacji nadawczo-odbiorczych itd.). Nie są one z góry zakładane, ale każdorazowo określane na podstawie wnikliwego wglądu w materiał (kodowanie otwarte - zob. w poprzednim rozdziale i Babbie 2004: 626-627; Gibbs 2011: 91).

\subsubsection{Pytania badawcze i hipotezy}

W referowanych niżej badaniach starano się określić, jaki wizerunek przedstawiciela dyskursu popularnonaukowego występuje w jego tekstach pisanych oraz za pomocą jakich wykładników dyskursowych komunikowane są dwie z cech autora książek: „pasjonat” oraz „ma dużą wiedzę historyczną”. Zakładano, że w wizerunku książkowym (na podstawie tekstów) dominują cechy dotyczące wiedzy prowadzącego (np. „ma wiedzę”), poczucia humoru („zabawny”) i komunikatywności („komunikatywny”). Postawiono także hipotezę, że cecha „pasjonat” komunikowana jest za pomocą wykładników bazujących na deklaracjach o zaangażowaniu i szukaniu informacji historycznych, natomiast cechę „ma dużą wiedzę historyczną" wyraża się głównie za pomocą wykorzystania nazw własnych (miejsca, nazwiska, nazwy wydarzeń), oceny opisywanej sytuacji historycznej (jej diagnozy), podawania detali, osadzenia w czasie, deklaracji zdobywania/szukania informacji i używania wyszukanego słownictwa, jak np. nazwy stopni wojskowych czy jednostek bojowych - innymi słowy, cecha ta będzie miała analogiczne wykładniki do cechy „znawca tematu” (wykładniki te znane są z obszernej

14 Zamiennie stosuję określenia „wykładnik komunikacyjny” i „wykładnik dyskursowy” czy „wykładnik dyskursywny”. 
analizy wypowiedzi felietonistów w Barańska-Szmitko 2018: 126-140). Wyjątek stanowić może wykładnik relacjonowanie/informowanie, ponieważ narracja jest niezbędna i oczywista w wywodzie historycznym, a jako taka zapewne nie zwraca uwagi, więc może się nie pojawić wśród wykładników przypisywanej historykowi cechy „ma wiedzę”.

\subsubsection{Material badawczy}

W części eksperymentalnej (jej opis niżej - czytanie tekstu, przypisywanie cech i przytaczanie cytatów je aktualizujących) wykorzystano trzy teksty Wojciecha Drewniaka: „Niemożliwe? Dajcie to Polakom! - bitwa o Monte Cassino” (2018: 219-241), „To on - typ pokorny - Tadeusz Rozwadowski” (2017: 181-204) oraz transkrypcję odcinka Historia Bez Cenzury zatytułowanego „Armie na haju: narkotyki II wojny światowej” ${ }^{15}$. W ostatnim przypadku zdecydowano się na wykorzystanie transkrypcji, by uczynić tematykę filmów bardziej różnorodną, a ponadto $\mathrm{w}$ książkach publikowanych przez Wojciecha Drewniaka ${ }^{16}$ pojawiają się rozdziały będące rozszerzoną wersją youtube'owych odcinków Historii Bez Cenzury (te same teksty z kilkoma nowymi wątkami). Skoro więc dyskurs książkowy jest bardzo zblizzony do dyskursu z serwisu społecznościowego, to uznano, że w tym przypadku można użyć różnych tekstów w tym samym badaniu.

Teksty przedstawione respondentom nieco skrócono w stosunku do oryginału, tak by całość badania nie zajmowała uczestnikom więcej niż 20-25 min. W procesie zmniejszania obszerności tekstów zadbano o to, by wykorzystana w badaniu wersja tekstu zachowała swoją komunikatywność oraz linearność (jeśli taka występowała) i logikę wywodu. Wycinano fragmenty, nie umieszczano w tekście niczego dodatkowego. Usunięcia zaznaczano wielokropkiem w nawiasie ${ }^{17}$.

15 Wojciech Drewniak, „Armie na haju”, odcinek opublikowany 19.09.2019 na kanale Historia Bez Cenzury, https://www.youtube.com/watch?v=LLdtObjRHrA\& $\mathrm{t}=3$ s\&has_verified $=1$ [dostęp: 1.06 .2020 ].

${ }^{16}$ Do tej pory (czerwiec 2020) opublikował książki: Historia Bez Cenzury (2016), Historia Bez Cenzury 2. Polskie koksy (2017), Historia Bez Cenzury 3. Poland first to fight..., czyli II wojna światowa (2018), Historia Bez Cenzury 4. Średniowiecze bez trzymanki (2019).

${ }^{17}$ By dać lepsze wyobrażenie o badaniu i możliwych do osiągnięcia celach, warto zaznaczyć, że prezentowane niżej wyniki są częścią większego badania, w którym ustala się wizerunek youtubera prowadzącego kanał popularnonaukowy, a także ustala się wykładniki komunikacyjne poszczególnych cech wizerunkowych, uwzględniając wizerunek multimodalny (tak nazwijmy wizerunek konstruowany na podstawie obejrzanego przez widza filmu) oraz wizerunek werbalny/tekstowy (konstruowany 


\subsubsection{Procedura badawcza}

Zważywszy na cele badawcze i ograniczenia wynikające z pandemii Covid- $19^{18}$, procedurę badawczą należy opisać, uwzględniając dwie jej części: pierwszą, w której wyłoniono cechy wizerunkowe Wojciecha Drewniaka jako autora książek, i drugi etap, służący określeniu wykładników komunikacyjnych cechy wizerunkowej „pasjonat” oraz „ma wiedzę”. Ze względu na utrudnienia pandemii nie udało się uzyskać pełnej spójności między tymi częściami. Należało posłużyć się zarówno tradycyjną formą uczestnictwa respondentów w badaniu, jak i wersją zapośredniczoną internetowo. Całość miała dość skomplikowany przebieg, którego opis zostaje tutaj, ze względu na obszerność rozdziału, ograniczony do najważniejszych elementów.

\subsubsection{Zadania dla respondentów}

W pierwszej części badania respondenci czytali jeden z dwóch lub trzech tekstów Wojciecha Drewniaka i odpowiadali na pytanie: „Mając za podstawę przeczytany fragment książki Historia Bez Cenzury 3, jakimi słowami opisałby Pan/opisałaby Pani autora Wojciecha Drewniaka?". Gdy tekst dotyczył fragmentu Historii Bez Cenzury 2, wówczas odpowiednio modyfikowano pytanie. Gdy test był adaptowaną wersją wypowiedzi z filmu (o tym niżej), użyto sformułowania: „Mając za podstawę przeczytany fragment tekstu, jakimi słowami opisałby Pan/opisałaby Pani autora Wojtka Drewniaka?”. Uczestnicy badania mieli do dyspozycji kartkę formatu A5 na odpowiedzi, a w wersji internetowej pustą przestrzeń do wypełniania zapisem dowolnej długości. Odpowiedź na powyższe pytanie pozwoliła wskazać cechy wizerunkowe przypisywane Wojciechowi Drewniakowi.

Dane do części drugiej, czyli wypisane z tekstu fragmenty, wyrażające cechę „pasjonat” lub „ma wiedzę”, pozyskiwano na dwa sposoby. Uwzględniano w korpusie badanych cytatów takie, które respondenci wypisali w ramach realizacji zadania: „Proszę wypisać z przeczytanego tekstu słowa, zdania bądź fragmenty, które Pana/Pani zdaniem świadczą o tym, że Wojciech Drewniak to PASJONAT” (dla „ma wiedzę” pytanie miało tę cechę wymienioną na końcu zdania). Dzięki

na podstawie przeczytanego tekstu) i wykładniki dyskursowe służące komunikowaniu poszczególnych cech każdego z tych typów wizerunku w dyskursie popularnonaukowym w jego wersji werbalnej i audiowizualnej. Wybrano historyków: Wojciecha Drewniaka i Jakuba Czerwińskiego, prowadzących odpowiednio kanały Historia Bez Cenzury oraz Irytujacy historyk.

18 12.03.2020 roku wprowadzono kwarantannę narodową w Polsce, co spowodowało znaczące ograniczenia, uniemożliwiające pozyskanie większej liczby respondentów i tym samym dużej bazy materiałowej. 
temu wszyscy uczestnicy biorący udział $\mathrm{w}$ badaniu w określonym czasie mieli szansę podać cytaty do analizowanych cech wizerunkowych. Brano jednak pod uwagę również cytaty z tekstu, jeśli pierwsze pytanie dotyczyło podania cech wizerunkowych, a drugie brzmiało: „Proszę do każdej wskazanej przez Pana/Panią cechy Wojtka Drewniaka wypisać z tekstu słowa/zdania/fragmenty, które stały się podstawą do wyłonienia danej cechy", i wtedy, gdy uczestnik badania przypisał cechy „pasjonat” lub „ma wiedzę”. Wówczas również i taki cytat uwzględniano $\mathrm{w}$ bazie materiałowej. Na innej kartce znajdowały się pytania metryczkowe i jedno dotyczące wcześniejszej znajomości autora tekstu ${ }^{19}$. W wersji internetowej były to kolejne pytania.

Badanie $\mathrm{w}$ tradycyjnej formie przeprowadzano, dzięki uprzejmości wykładowcy ${ }^{20}$, w sali wykładowej na samym początku zajęć (informacje o grupie respondentów, miejscu i czasie badania znajdują się w kolejnych częściach rozdziału). Przeprowadzała je autorka niniejszego opracowania, by mieć świadomość warunków badania i kontrolę nad nimi. Kiedy wykładowca zapowiedział przeprowadzenie badania, studenci otrzymywali informację, iż „badanie dotyczy youtubera Wojciecha Drewniaka, który pisze też książki. Polega na przeczytaniu tekstu i odpowiedzi na kilka pytań, co powinno zająć łącznie ok. 20 min. Ankieta nie sprawdza czytania ze zrozumieniem. Udział w badaniu jest w pełni dobrowolny i anonimowy. Czy wyrażacie Państwo zgodę na udział w badaniu?”. Do tych, którzy wyrazili zgodę, kierowano następnie wypowiedź, w której podkreślano, że „na kartkach z tekstem i pytaniami zawsze należy zwracać uwagę na to zadanie, które jest na wierzchu udostępnionych kartek i przechodzi się do kolejnego zadania dopiero wówczas, gdy skończy się aktualne. Nie można sprawdzać, jakie są kolejne zadania, ale można jak najbardziej wracać do poprzednich”. Zakładano, że znajomość kolejnych poleceń może mieć wpływ na wyniki, bo respondenci mogliby ułatwiać sobie realizację poleceń. Jeśli zauważono, że ktoś łamał tę regułę, taka osoba kontynuowała udział w badaniu, ale jej kwestionariusz nie był uwzględniany w analizie wyników. Informowano także studentów, iż „nie ma odpowiedzi nieprawidłowych. Wszystkie Państwa odpowiedzi są prawidłowe

19 Brzmienie pytania: „Czy zna Pan/Pani osobę publiczną Wojtka Drewniaka (autora tekstu Historia Bez Cenzury)?” i odpowiedzi do wyboru: „Tak, dobrze kojarzę”; „Coś słyszałem/słyszałam”; „Nie, nie znam w ogóle”. Podaję te dane dla przejrzystości i rzetelności opisu. Nie będą jednak w tym tekście analizowane. Obszerne badania na inny temat, przeprowadzone wśród ponad 500 osób, wykazały, że w przypadku czytania tekstu wplyw znajomości autora na wizerunek konstruowany na podstawie tekstu jest niewielki i choć przypisywane cechy występują w różnych proporcjach w zależności od tego, czy autor tekstu jest znany czytelnikowi bądź nie, to sam zakres cech się nie zmienia (przypisywane są wciąż te same cechy, zmieniają się jedynie ich proporcje ilościowe) (Barańska-Szmitko 2018a: 214).

${ }^{20}$ Dziękuje dr hab. prof. UŁ Monice Worsowicz za umożliwienie wejścia na zajęcia. 
i cenne dla badania. Bardzo proszę o odpowiedzi spontaniczne i szczere”. Wersja internetowa wyglądała identycznie, jeśli udało się pojawić na zajęciach dzięki możliwościom aplikacji MS Teams (niewykonalne było tylko zweryfikowanie, czy respondenci sprawdzają brzmienie kolejnych pytań). W czerwcu 2020 roku kilkanaście ankiet zebrano też poprzez przesłanie linku do ankiety i umieszczenie kluczowych informacji w zaproszeniu do ankiety. Poproszono wówczas wykładowców z kilku polskich uczelni o pomoc $\mathrm{w}$ dystrybucji zaproszenia do ankiet swoim studentom ${ }^{21}$. Do studentów dziennikarstwa I lub II roku kierowano następujące zaproszenie:

Ankieta dotyczy Wojciecha Drewniaka, youtubera, prowadzącego kanał Historia Bez Cenzury i autora książek o tym samym tytule. Należy przeczytać krótki fragment tekstu jednej z jego wypowiedzi, a następnie odpowiedzieć na zamieszczone niżej pytania. Pytania nie sprawdzają czytania ze zrozumieniem :) Ale do odpowiedzi potrzebne jest przeczytanie całego tekstu, o co bardzo proszę. Ankieta służy badaniom naukowym, jest dobrowolna i w pełni anonimowa. Jej wypełnienie powinno zająć ok. 12-20 minut (7-10 tekst i 5-10 pytania). Jeśli się zdecydujesz - dziękuję za poświęcony czas i uwagę! Bardzo mi pomożesz, wypełniając tę ankietę.

Pod zaproszeniem znajdował się link do ankiety ${ }^{22}$ z zaprezentowanymi wyżej pytaniami.

\subsubsection{Uczestnicy, czas i miejsce badania}

O udział w badaniu poproszono studentów dziennikarstwa i komunikacji społecznej I i II roku studiów licencjackich, zakładając, że są to studenci, którzy (zwłaszcza w etapie przypisywania cech wizerunkowych) będą potrafić „odpowiednie dać rzeczy słowo" i, relatywnie trafniej niż przedstawiciele innych kierunków, zwerbalizować skonstruowany wizerunek autora tekstu. Nie proszono

21 Proszono mailowo o wsparcie wykładowców z Uniwersytetu Wrocławskiego, Uniwersytetu Kazimierza Wielkiego w Bydgoszczy, Uniwersytetu Śląskiego, Uniwersytetu Adama Mickiewicza w Poznaniu, Uniwersytetu Śląskiego, Uniwersytetu Warszawskiego i Uniwersytetu Gdańskiego. Tylko część adresatów odpowiedziała. Dziękuję za pomoc następującym wykładowcom: dr. Michałowi Grali (UWr), dr Dorocie Kokowicz (UWr), dr. Wiesławowi Czechowiczowi (UKW w Bydgoszczy), dr Annie Sakson-Boulet (UAM), dr Grażynie Majkowskiej (UW), dr Dorocie Lewandowskiej-Jaros (UW), dr Annie Dąbkowskiej (UW), dr. hab. Krzysztofowi Kaszewskiemu (UW), prof. dr. hab. Radosławowi Pawelcowi (UW).

${ }^{22}$ A dokładnie jeden $\mathrm{z}$ trzech linków (każdy wykładowca otrzymywał inny link lub każda grupa studentów otrzymywała inny link): https://www.interankiety.pl/f/ r4EM98g4; https://www.interankiety.pl/f/dOW0xbmo; https://www.interankiety. pl/f/YNAlZ4KJ [dostęp: 30.06.2020]. 
o udział w badaniu studentów wyższych roczników ze względu na przewidywaną zbyt dużą świadomość języka, komunikacji, gatunku, stylu czy tropów retorycznych. Elokwencja uczestników nie była tak istotna w etapie zbierania fragmentów tekstu komunikujących dane cechy wizerunkowe, ale dla spójności grupy i rzetelności wyników stosowano te same zasady doboru respondentów.

Badanie w ramach pierwszej części, w której wyłoniono wizerunek Wojciech Drewniaka, przeprowadzono 6 listopada 2019 roku i 21 października 2020 roku, co pozwoliło zebrać 71 ankiet od studentów I roku dziennikarstwa i komunikacji społecznej Uniwersytetu Łódzkiego ( 29 w 2019 roku i 42 w 2020 roku). W pierwszym z tych terminów wykorzystano dwa rozdziały z książek historyka, $\mathrm{w}$ drugim terminie oprócz nich respondenci czytali też transkrypcję odcinka „Armie na haju".

Drugą część badania, w której pozyskiwano fragmenty tekstów komunikujące określone cechy wizerunkowe, realizowano razem z częścią pozyskiwania cech wizerunkowych w czasie i wśród respondentów opisanych powyżej (listopad 2019, październik 2019, studenci UŁ), a także w czerwcu 2020 roku (między 9 a 30 czerwca 2020 roku), kiedy wykładowcy dziennikarstwa i komunikacji społecznej kilku polskich uczelni (czytaj wyżej) przesłali swoim studentom zaproszenie do badania i linki do ankiet. Ostatecznie w czerwcu 2020 roku w badaniu wzięło udział bardzo mało osób, bo tylko 16, spośród których czwórka to studenci Uniwersytetu Adama Mickiewicza w Poznaniu, ośmioro reprezentuje Uniwersytet Kazimierza Wielkiego w Bydgoszczy i czterech respondentów wywodzi się z Uniwersytetu Warszawskiego ${ }^{23}$. Połowa $\mathrm{z}$ nich to studenci I roku, połowa - studenci II roku.

Nierówności liczbowe (zdecydowana większość uczestników z Uniwersytetu Łódzkiego, przewaga studentów I roku, nierówna liczba osób czytających ten sam tekst) wynikają z braku kontroli nad realizacją badania prowadzonego z konieczności $\mathrm{w}$ formie online $\mathrm{z}$ powodu pandemii. Pożądanym, a niestety tutaj nieosiągniętym efektem, powinno być przeczytanie każdego z tekstów przez tę samą liczbę osób, by zrównoważyć wpływ tematu na wizerunek historyka. Jedynym rozwiązaniem w takiej sytuacji jest baczniejsze uwzględnienie tych dysproporcji $\mathrm{w}$ analizie.

\subsubsection{Wizerunek Wojciecha Drewniaka komunikowany w jego tekstach}

Pierwsza część badania pozwoliła ustalić wizerunek Wojciecha Drewniaka. Zebrane określenia, przypisywane przez respondentów, poddano kodowaniu otwartemu i po uważnym wglądzie w materiał wszystkie przypisane, różne

23 Nie wzięli udziału w ogóle studenci z Uniwersytetu Wrocławskiego, choć ich wykładowcy potwierdzili przekazanie informacji o badaniu. 
epitety uporządkowano w spójne cechy wizerunkowe (zob. o kodowaniu cech wizerunkowych szerzej w poprzednim rozdziale).

71 osób podało łącznie 262 określenia, które skodowano w spójne cechy wizerunkowe, zaprezentowane w tabeli 1 . „N wskazań” określa, ile razy podano daną cechę wizerunkową w tym etapie badania; „\% wskazań” informuje o wartościach procentowych, tj. jaki procent wszystkich wskazań reprezentują wskazania danej cechy wizerunkowej. „N osób” ukazuje, ile osób przypisało daną cechę wizerunkową (osób przypisujących cechę wizerunkową może być mniej niż wskazań, wówczas gdy dana osoba dwa razy przypisze tę samą cechę, posługując się jej synonimicznymi określeniami). „\% osób” to dane informujące o tym, ile procentowo respondentów wskazało daną cechę wizerunkową. Ponieważ każda z osób podała więcej niż jedną cechę, w przypadku wyników dotyczących uczestników badania, dane nie sumują się do 71 (liczba uczestników) ani do $100 \%$.

Tabela 1. Wizerunek Wojciecha Drewniaka, komunikowany w jego tekstach

\begin{tabular}{|l|l|c|c|c|c|}
\hline Lp. & \multicolumn{1}{|c|}{ Cecha wizerunkowa } & N wskazań & \% wskazań & N osób & \% osób \\
\hline 1 & bezpośredni & 52 & 19,8 & 45 & 63,4 \\
\hline 3 & zabawny & 33 & 12,6 & 31 & 43,7 \\
\hline 2 & ma wiedzę & 21 & 8,0 & 20 & 28,2 \\
\hline 4 & pasjonat & 17 & 6,5 & 16 & 22,5 \\
\hline 5 & ciekawy & 14 & 5,3 & 13 & 18,3 \\
\hline 6 & inteligentny & 13 & 5,0 & 12 & 16,9 \\
\hline 7 & komunikatywny & 11 & 4,2 & 10 & 14,1 \\
\hline 8 & młodzieżowy & 10 & 3,8 & 10 & 14,1 \\
\hline 9 & kolokwialny styl wypowiedzi & 10 & 3,8 & 9 & 12,7 \\
\hline 10 & wyluzowany & 8 & 3,1 & 8 & 11,3 \\
\hline 11 & patriota & 8 & 3,1 & 7 & 9,9 \\
\hline 12 & wygadany & 7 & 2,7 & 7 & 9,9 \\
\hline 14 & oczytany & 6 & 2,3 & 6 & 8,5 \\
\hline 15 & szczery & 6 & 2,3 & 6 & 8,5 \\
\hline 16 & niekonwencjonalny & 7 & 2,7 & 5 & 7,0 \\
\hline 17 & przyjemnie pisze & 5 & 1,9 & 4 & 5,6 \\
\hline 18 & inne & 262 & 100,0 & & 45,1 \\
\hline & razem & 13,0 & 32 & \\
\hline
\end{tabular}

Źródło: opracowanie własne. 
Jak ukazuje powyższa tabela, dwoma najczęściej przypisywanymi określeniami są „bezpośredni” oraz „zabawny”. Wydają się znaczące dla wizerunku, jeśli zważyć na fakt, że niemal 1/5 wskazań ( 52 wskazania - 19,8\%) dokonanych przez ponad połowę czytających (45 osób - 63,4\%) dotyczy pierwszej z tych cech, a $12,6 \%$ przypisań $(12,6 \%)$ wynotowanych przez niemal połowę uczestników badania (43,7\%) wskazuje na drugą z nich. Zdecydowana postawa historyka oraz poczucie humoru wydają się najistotniejsze liczbowo dla youtubera-pisarza. Niemal jedna trzecia uczestników badania ma autora Historii Bez Cenzury za człowieka kompetentnego (cecha „ma wiedzę”, wskazana 21 razy - 8,0\% przez $28,2 \%$ respondentów). Około jedna piąta czytających widzi w piszącym „pasjonata”, osobę „ciekawą" i inteligentną" (odpowiednio wskazań: $17-6,5 \%, 14-5,3 \%$, 13 - 5,0\% i odpowiednio osób: $22,5 \%, 18,3 \%, 16,9 \%)$. Trochę ponad $10 \%$ uczestników badania przypisało historykowi cechy wiążące się ze stylem jego wypowiedzi, takie jak: „komunikatywny” i „młodzieżowy” (cechy wskazane odpowiednio 11 razy $-4,2 \%, 10-3,8 \%$, przypisane przez równo 10 osób - 14,1\% czytających), a także „kolokwialny styl wypowiedzi” (zauważony 10 razy - 3,8\% przez 9 uczestników badania, czyli 12,7\%) czy „wyluzowany” ( 8 wskazań - 3,8\%, 8 respondentów $-11,3 \%)$. Mniej niż 10\% respondentów przypisało takie cechy wizerunkowe jak: „patriota” ( 8 wynotowań - 3,1\%, 7 osób - 9,9\%) i „wygadany” ( 7 wskazań $-2,7 \%, 7$ respondentów $-9,9 \%)$, „oczytany” i „szczery” (6 przypisań $-2,6 \%$, dokonanych przez 6 czytających - 8,5\%), „niekonwencjonalny” (7 wskazań - 2,7\%, 5 respondentów $-7 \%$ ), „przyjemnie pisze” (5 wskazań - 1,9\%, 4 uczestników badania - 5,6\%). Pozostałych określeń nie udało się skategoryzować w spójne cechy wizerunkowe (kategoria „inne” - 13,0\% wskazań wypisanych przez 45,1\% respondentów).

Jeśli połączyć powyższe cechy w grupy cech synonimicznych, zbliżonych semantycznie, wyrażających podobne atrybuty wizerunkowe (nazwijmy to blokami semantycznymi, widocznymi w tabeli 2), to zwróci uwagę zdecydowana postawa Wojciecha Drewniaka („bezpośredni”, „szczery”) oraz cechy komunikujące atrakcyjność i przystępność przekazu historyka („ciekawy”, „komunikatywny”, „kolokwialny styl wypowiedzi”, „wygadany”, „przyjemnie pisze"). Możliwe, że oba te wyróżniki miały wpływ na uznanie historyka za osobę kreatywną z poczuciem humoru („zabawny”, „niekonwencjonalny”), a jednocześnie kompetentną („ma wiedzę”, „inteligentny”, „oczytany”). Nie bez znaczenia wydaje się, że wie, jak trafić do młodego odbiorcy i jest "na czasie” („młodzieżowy”, „wyluzowany”). Widoczna też jest jego pasja („pasjonat") i w najmniejszym stopniu postawa wobec swojego kraju. Z tego obrazu wyłania się postać Wojciech Drewniaka, który w sposób zdecydowany, atrakcyjny i przystępny, „na czasie”, zarówno z dystansem, jak i kompetentnie przedstawia swoją pasję. 
Tabela 2. Bloki semantyczne wizerunku Wojciecha Drewniaka, komunikowanego w jego tekstach

\begin{tabular}{|l|c|c|c|c|}
\hline \multicolumn{1}{|c|}{ Cecha wizerunkowa } & N wskazań & \% wskazań & N osób & \% osób \\
\hline bezpośredni & 52 & 19,8 & 45 & 63,4 \\
\hline szczery & 6 & 2,3 & 6 & 8,5 \\
\hline Blok: zdecydowana postawa & 58 & 22,1 & & \\
\hline ciekawy & 14 & 5,3 & 13 & 18,3 \\
\hline komunikatywny & 11 & 4,2 & 10 & 14,1 \\
\hline kolokwialny styl wypowiedzi & 10 & 3,8 & 9 & 12,7 \\
\hline wygadany & 7 & 2,7 & 7 & 9,9 \\
\hline przyjemnie pisze & 5 & 1,9 & 4 & 5,6 \\
\hline Blok: przystępny i atrakcyjny & 47 & 17,9 & & \\
\hline zabawny & 33 & 12,6 & 31 & 43,7 \\
\hline niekonwencjonalny & 7 & 2,7 & 5 & 7,0 \\
\hline Blok: z dystansem & 40 & 15,3 & & \\
\hline ma wiedzę & 21 & 8,0 & 20 & 28,2 \\
\hline inteligentny & 13 & 5,0 & 12 & 16,9 \\
\hline oczytany & 6 & 2,3 & 6 & 8,5 \\
\hline Blok: kompetentny & 40 & 15,3 & & \\
\hline młodzieżowy & 10 & 3,8 & 10 & 14,1 \\
\hline wyluzowany & 8 & 3,1 & 8 & 11,3 \\
\hline Blok: „na czasie” & 18 & 6,9 & & \\
\hline pasjonat (?) & 17 & 6,5 & 16 & 22,5 \\
\hline patriota & 8 & 3,1 & 7 & 9,9 \\
\hline
\end{tabular}

Źródło: opracowanie własne.

Tak określony wizerunek, choć wyłoniony z niewielu ankiet, pozwala już zauważyć zjawiska warte dalszego badania.

\subsubsection{Komunikowanie cech wizerunkowych}

Z powyższych cech wizerunkowych wybrano dwie jako przedmiot referowanej w niniejszym rozdziale analizy, każdą z innych powodów. „Pasjonat” to cecha, która zaskakuje, jeśli wziąć pod uwagę fakt, że prowadzącym wideoblog i autorem książek z cyklu Historia Bez Cenzury jest osoba opisująca zagadnienia historyczne. Naturalne wydaje się postrzeganie Wojciecha Drewniaka jako „history- 
ka”, „osobę wykształconą” czy też po prostu „mającą wiedzę”. I takie określenia też padały, ale oprócz nich także dość często „pasjonat”, co rodzi pytanie: czym pasjonowanie się tematem różni się od posiadania wiedzy, skoro wiedza powinna być kluczowa zarówno dla cechy „pasjonat”, jak i „ma dużą wiedzę”?

\subsubsection{Wykładniki komunikacyjne cechy „pasjonat”}

Udało się uzyskać łącznie 61 fragmentów, wyrażających cechę wizerunkową „pasjonat”, które wynotowało 61 osób, a każda z nich czytała jeden z trzech różnych tekstów Wojciecha Drewniaka. Brak możliwości pełnej kontroli nad warunkami badania, spowodowany przez pandemię koronawirusa, wpłynął na brak proporcji między tekstami a liczbą respondentów, tj. tekst o zdobyciu Monte Cassino czytało znacznie więcej osób ( 27 uczestników badania) niż pozostałe teksty (17 i 18 osób).

Tabela 3. Liczba uzyskanych ankiet z fragmentami komunikującymi cechę „pasjonat”

\begin{tabular}{|l|c|c|c|c|}
\hline \multicolumn{1}{|c|}{ Data badania } & Monte Cassino & Rozwadowski & Armie na haju & Razem \\
\hline 6.11 .2019 & 6 & 3 & 7 & 16 \\
\hline $9-30.06 .2020$ & 9 & 3 & 0 & 12 \\
\hline 21.10 .2020 & 11 & 11 & 11 & 33 \\
\hline Razem & 26 & 17 & 18 & 61 \\
\hline
\end{tabular}

Źródło: opracowanie własne.

W procesie kodowania otwartego przeanalizowano wszystkie cytaty pod względem ich wizerunkowej funkcji (komunikowanie cechy „pasjonat”). Mając na uwadze synonimiczność stosowanych przez respondentów określeń oraz spójność stosowanych zabiegów dyskursowych w obrębie korpusu cytatów (o procesie kodowania zob. w poprzednim rozdziale), starano się wyłonić sposoby werbalnego komunikowania cechy „pasjonat”, czyli jej wykładniki komunikacyjne/ dyskursowe.

Wśród wykładników komunikacyjnych cechy wizerunkowej „pasjonat” wymienić należy podkreślenie dużego znaczenia kogoś lub czegoś, podawanie szczegółów historycznych, podkreślanie wiedzy („wyjaśniam”) i deklarowanie znajomości literatury przedmiotu. Dane procentowe podawane są dla porządku. Niewielka obszerność materiału i brak postulowanych proporcji ogranicza miarodajne wnioskowanie na podstawie poniższych danych.

Podkreślenie dużego znaczenia kogoś lub czegoś pojawiało się 24 razy wśród 61 cytatów, a zatem w 39,3\% wszystkich wynotowanych przez respondentów fragmentów, dotyczących cechy „pasjonat”. Istotą tego wykładnika są 
superlatywy wyrażone różnymi sposobami, np. przymiotnikami w stopniu najwyższym, jak widać poniżej

- ... z których jedna - „Husky” - jest chyba najbardziej niedocenioną operacją II wojny światowej (MC) ${ }^{24}$

- jeden z naszych największych bohaterów (Rozwadowski)

również zaznaczenie liczebności bądź porównanie może służyć uwypukleniu istotności zjawiska, np.

- Pamiętajmy o nich, bo na pamięć innych ciężko liczyć; ale po posłużeniu się kalkulatorem wyszło mi, że dawało to codziennie mniej więcej 1200 ofiar po obu stronach (MC)

- a pamiętajmy, że ówczesna broń nijak się miała pod względem celności do tej dzisiejszej (Rozwadowski) [o strzeleniu odstrzeleniu ptakowi głowy z odległości 300 metrów podczas polowania - przyp. A.B.-S.]

W celu ukazania znaczenia bywają też użyte leksemy silnie wartościujące negatywnie bądź pozytywnie.

- „Niemożliwe? Dajcie to Polakom!”; „mogła okazać się jedną z największych wtop”; „rozwalenie bezcennego klasztoru i obcinanie głów hitlerowcom wielkimi nożami”; „takimi samymi zwierzętami jak naziści”; „swoją ofiarną postawą"; „wiedzieli to już Arabowie setki lat temu”; „mieli teraz świetny przyczółek [...], ale też ekstra bazę wypadową"; „Do miejsca będącego od wieków koszmarem każdego wojskowego stratega”; „kto zdobył Monte Cassino, mial otwartą drogę do Wiecznego Miasta”; „Masyw górski poprzecinany wąskimi gardłami skalnymi”; „Stworzyli tam tzw. Linię Gustawa - pas potwornych umocnień” (MC)

Podkreślenie dużego znaczenia kogoś lub czegoś zwykle realizowane jest, by wyrazić podziw, docenienie czy uznanie („najbardziej niedoceniona operacja”, „bezcenny klasztor”, „ofiarna postawa”), ale bywa też użyte w celu podkreślenia dużego negatywnego znaczenia („zwierzętami jak naziści”, „koszmar”, „potworne”).

Drugim z wykładników komunikowania pasjonowania się (historią) jest posługiwanie się szczegółami historycznymi (też „pozapodręcznikowymi”). Wykładnik ten występuje w 18 na 61 cytatów, co stanowi 29,5\% całości. Respondenci wynotowali np. takie fragmenty:

${ }^{24} \mathrm{~W}$ nawiasach po cytatach pojawia się skrót od tytułu tekstu czytanego przez respondentów. „MC” to rozdział „Niemożliwe? Dajcie to Polakom! - bitwa o Monte Cassino” (Drewniak 2017: 181-204); „Rozwadowski” - „To on - typ pokorny - Tadeusz Rozwadowski” (Drewniak 2018: 219-241), a „Armie na haju” to odesłanie do tekstu filmu „Armie na haju”, który został opublikowany 19.09.2019 na kanale Historia Bez Cenzury. 
- Walki trwały całą noc, aż wreszcie w okolicach 8.45 przyszedł czas na ostateczne rozwiązanie kwestii niemieckiej na Monte Cassino (MC)

- Hipotezy są dwie - pierwsza mówi, że ściany w jego celi pomalowano specjalną farbą z arszenikiem. Inni z kolei twierdzą, że generała otruto już po wyjściu z pierdla - wracając do Warszawy, miał dostać kanapkę z drobno pociętym końskim włosiem, co miało doprowadzić do owrzodzenia żołądka (znajomość szczególów niepodawanych w podstawowych ogólnych źródłach) (Rozwadowski)

- Malował sobie paznokcie, nakładał makijaż, zakładał delikatny szlafroczek i tak see latał po chałupie (Armie na haju) [o zachowaniu Hermana Goeringa, będącego pod wpływem narkotyków [przyp. A.B.-S.]

Wśród szczegółów wymienianych w wywodach Wojciecha Drewniaka pojawiają się takie, które wymykają się tradycyjnemu dyskursowi historycznemu w jego podręcznikowej wersji i można przypuszczać, że źródłem tych wiadomości są niekoniecznie oficjalne dokumenty (zob. wyżej przykład zwłaszcza dot. Hermana Goeringa).

Zaznaczyć przy tym należy, że podawanie szczegółów historycznych może być typowe wyłącznie dla „pasjonata” - historyka, a prawdopodobnie pasjonat innej dziedziny wiedzy wymieniałby szczegóły dotyczące typowych dla siebie zagadnień, choć oczywiście to spostrzeżenie wymaga badań wśród „pasjonatów”, reprezentujących inne nauki.

Trzeci z wykładników omawianej cechy to zaznaczanie swojej dużej wiedzy, które skrótowo ujęte tu zostaje jako „wyjaśniam”. Ten wykładnik pojawił się tylko osiem razy $(13,15 \%)$, na przykład w następujących cytatach:

- Zaczniemy trochę banalnie, ale wolę się upewnić, że wszyscy wiedzą, gdzie jest Monte Cassino (MC)

- Co takiego się tam stało? Już tłumaczę (Rozwadowski)

- czy w związku z tym ciężko było ją dostać? Gdzie tam! (Armie na haju)

Autor tekstu zaznacza, że ma obszerną wiedzę, z której czerpie informacje na potrzeby prowadzonego wywodu i z myślą o odbiorcy. Warto zauważyć, że ten wykładnik oprócz tego, że podkreśla wiedzę historyka, to na poziomie organizacji wypowiedzi służy jej porządkowaniu. Pierwszy z cytatów to początek tekstu i wprowadzenie w temat, drugi występuje po ocenie bitwy i stanowi wstęp do jej opisu. Trzeci wewnątrz tekstu przenosi do kolejnego wątku. Jednocześnie „wyjaśniam” (przynajmniej we fragmentach dostępnych na tym etapie badań) realizuje jeden $\mathrm{z}$ wyznaczników stylu popularnonaukowego, tj. dialogowość (Starzec 2013: 84-85; Maciejak 2018: 116-118) - w obu przykładach Wojciech Drewniak bezpośrednio zwraca się do swoich czytelników, jak gdyby z nimi rozmawiał. Relatywnie niska reprezentatywność tego wykładnika może wynikać z jego funkcji tekstowej. Porządkowanie wypowiedzi występuje znacznie rzadziej niż opis z użyciem wartościujących epitetów czy szczegółów. 
Czwartym wykładnikiem dyskursywnym cechy „pasjonat” jest odwoływanie do literatury przedmiotu, które pojawiło się w analizowanym korpusie siedem razy $(11,5 \%)$. Uczestnicy badania podali na przykład takie fragmenty:

- O tym możecie się dowiedzieć z [mojej - przyp. A.B.-S.] poprzedniej książki (Rozwadowski)

- koniecznie sięgnijcie po książkę Dragi i wojna (Armie na haju)

Bardzo możliwe, że niska reprezentatywność tego wykładnika - podobnie jak $\mathrm{w}$ poprzednim przypadku - również wynika z rzadkiego stosowania tego typu odwołań.

Pojawiły się także cztery wypowiedzi, które skategoryzowano jako „inne”. Są to następujące uwagi uczestników badania:

- Cały tekst dowodzi oddania temu, co robi (MC)

- Monte Cassino powtórzone bardzo dużo razy (MC)

- Uważam, że to nie słowa świadczą o tym, że Wojciech Drewniak to pasjonat, a klimat i przekaz całego tekstu, który on sam stworzyl. To się po prostu czuje (MC)

- Generał Rozwadowski, jak to było w jego zwyczaju, nie lubił się obijać, nawet jeśli miał wreszcie na to czas (Rozwadowski)

Na podstawie tych „innych” odpowiedzi nie udało się ustalić żadnego spójnego sposobu komunikowania cechy „pasjonat”.

Jak widać, komunikowanie cechy wizerunkowej „pasjonat” w przypadku Wojciecha Drewniaka realizuje się za pomocą czterech wykładników: podkreślania dużego znaczenia, wymieniania szczegółów, wskazywania na swoją obszerną wiedzę udostępnianą czytelnikowi („wyjaśniam”) oraz odwoływania się do literatury przedmiotu. Jak pokazuje tabela 4, w komunikowaniu omawianej cechy zdecydowanie dominuje podkreślenie dużego znaczenia kogoś lub czegoś, a także posługiwanie się szczegółami (w tym pozapodręcznikowymi). „Wyjaśniam” oraz odwoływanie do literatury przedmiotu ma zdecydowanie mniejsze znaczenie, co może wynikać z funkcji tekstowych tych wykładników, powodujących niskie ich nasycenie w tekstach.

Warto się jeszcze przyjrzeć widocznemu w tabeli 4 rozkładowi wykładników wśród poszczególnych tekstów, ponieważ zauważyć się da pewną zależność użycia określonych wykładników od tematu wypowiedzi i/lub od medium oraz warunków finansowania. Teksty dot. Monte Cassino i Rozwadowskiego wyraźnie służyły podkreśleniu bohaterskości polskich żołnierzy we Włoszech oraz ukazaniu wielkości polskiego generała początku XX wieku. W obu przypadkach hiperbolizacje wspierają tę optykę. Trudno o takie spojrzenie w przypadku tekstu opisującego zażywanie narkotyków w armiach podczas II wojny światowej. Przeglądowy charakter tego tekstu zmniejsza potrzebę intensywnego posługiwania się uznaniem dla kogoś lub czegoś. W przypadku odwoływania się do literatury przedmiotu, należy zwrócić uwagę, że niemal wszystkie cytaty pochodzą z tekstu 
filmu „Armie na haju”, który prawdopodobnie był sponsorowany i służył promocji wymienionej w wypowiedzi pozycji książkowej. Inny cytat dotyczy odwołania do innej książki Wojciecha Drewniaka, więc służy tym razem autopromocji. Badanie na większym korpusie tekstów mogłoby pomóc potwierdzić lub negatywnie zweryfikować zarysowany tu trop interpretacyjny.

Tabela 4. Wykładniki komunikacyjne cechy wizerunkowej „pasjonat”

\begin{tabular}{|l|c|c|c|c|c|}
\hline $\begin{array}{c}\text { „Pasjonat”-wykładnik } \\
\text { komunikacyjny }\end{array}$ & $\begin{array}{c}\text { Monte } \\
\text { Cassino }\end{array}$ & $\begin{array}{c}\text { Rozwa- } \\
\text { dowski }\end{array}$ & $\begin{array}{c}\text { Armie } \\
\text { na haju }\end{array}$ & $\begin{array}{c}\text { Liczba } \\
\text { cytatów }\end{array}$ & $\begin{array}{c}\text { \% } \\
\text { cytatów }\end{array}$ \\
\hline $\begin{array}{l}\text { podkreślenie dużego zna- } \\
\text { czenia kogoś lub czegoś }\end{array}$ & 11 & 10 & $\mathbf{3}$ & $\mathbf{2 4}$ & $\mathbf{3 9 , 3}$ \\
\hline szczegóły historyczne & 8 & 5 & 5 & $\mathbf{1 8}$ & $\mathbf{2 9 , 5}$ \\
\hline wyjaśniam & 3 & 4 & 1 & $\mathbf{8}$ & $\mathbf{1 3 , 1}$ \\
\hline $\begin{array}{l}\text { odwoływanie } \\
\text { do literatury przedmiotu }\end{array}$ & 0 & 1 & $\mathbf{6}$ & $\mathbf{7}$ & $\mathbf{1 1 , 5}$ \\
\hline inne & 3 & 1 & 1 & $\mathbf{4}$ & $\mathbf{6 , 6}$ \\
\hline razem & 25 & 20 & 17 & 61 & 100,0 \\
\hline
\end{tabular}

Źródło: opracowanie własne.

Wyżej przeprowadzona analiza jakościowa i ilościowa pozwalają wnioskować, że duże dysproporcje ilościowe między dominującymi a marginalnymi wykładnikami mogą zależeć od częstości występowania charakterystycznych dla wykładników zabiegów dyskursowych, która to częstość uwarunkowana jest organizacją i funkcjonalnością tekstu. Zupełnie naturalne w dyskursie popularnonaukowym wydaje się dużo liczniejsze posługiwanie się epitetami czy detalami historycznymi niż wprowadzanie w temat czy wyjaśnienia albo odwoływanie do literatury przedmiotu. Skoro więc pewne zabiegi dyskursowe występują częściej, to też częściej są wskazywane jako służące komunikowaniu cechy „pasjonat”. Pamiętać przy tym należy, że tematyka danego tekstu może wpływać na niższą reprezentatywność niektórych wykładników (np. mniej wyrażania uznania w tekstach "przekrojowych”, dotyczących opisu nie osoby czy wydarzenia, ale określonego problemu historycznego), a odwoływanie do literatury przedmiotu może wynikać ze zobowiązań promocyjnych autora wypowiedzi. Ze względu na niewielką liczbę ankiet, formułowane tu interpretacje traktować należy jako pewne trendy do zweryfikowania w obszerniejszych badaniach.

\subsubsection{Wykładniki komunikacyjne cechy „ma dużą wiedzę”}

Łącznie 71 osób podało cytaty komunikujące cechę „ma dużą wiedzę”, z czego 20 osób wypisało istotne dla nich fragmenty w listopadzie 2019 roku, 17 w czerwcu 2020 roku i 34 w październiku 2020 roku. Piątka spośród respondentów podała 
dwa cytaty, zakwalifikowane na etapie kodowania jako reprezentacje więcej niż jednego wykładnika, stąd też o pięć więcej, czyli 76 skodowanych cytatów występuje w bazie materiałowej.

Tabela 5. Liczba osób wynotowujących fragmenty komunikujące cechę „ma wiedzę”

\begin{tabular}{|l|c|c|c|c|}
\hline \multicolumn{1}{|c|}{ Data badania } & Monte Cassino & Rozwadowski & Armie na haju & Razem \\
\hline 6.11 .2019 & 13 & 7 & 0 & $\mathbf{2 0}$ \\
\hline $9-30.06 .2020$ & 8 & 4 & 5 & $\mathbf{1 7}$ \\
\hline 21.10 .2020 & 10 & 11 & 13 & $\mathbf{3 4}$ \\
\hline & 31 & 22 & 18 & 71 \\
\hline
\end{tabular}

Źródło: opracowanie własne.

Ze względu na konieczność i trudności w przeprowadzeniu badania w czasie pandemii, nie udało się uzyskać pełnej proporcji między tekstami i rozdział poświęcony zdobyciu Monte Cassino czytany był zdecydowanie częściej (31 razy) niż pozostałe (22 i 18 razy), co należy uwzględnić w interpretacji wyników.

Dostępne 76 cytatów poddano kodowaniu otwartemu, w wyniku czego określono wykładniki komunikacyjne/dyskursowe cechy wizerunkowej „ma dużą wiedzę", wśród których wymienić można: wskazywanie dat/godzin, przywoływanie informacji nieoficjalnych/pozapodręcznikowych, ukazywanie kontekstu wydarzeń, wymienianie danych liczbowych oraz posługiwanie się nazwami wydarzeń historycznych.

Najczęstszym sposobem komunikowania wiedzy (historycznej) jest przywoływanie dokładnych dat, a nawet godzin. Respondenci podali 20 takich cytatów, co stanowi $26,3 \%$ całego korpusu dla omawianej cechy. Wynotowano np.

- operacja „Husky”, która zaczęła się 10 lipca 1943 roku (MC)

- że Tadek, który przyszedł na świat 19 maja 1866 roku (Rozwadowski)

- 28 października 1918 roku powołano go na stanowisko szefa Sztabu Generalnego (Rozwadowski)

- bo morfinę wyizolowano z opium już w roku 1804; W 1937 roku zadebiutowała na rynku farmaceutycznym jako Pervitin (Armie na haju)

- Zacznijmy od używki bardzo popularnej, zwłaszcza wśród elit i to od XIX wieku, bo morfinę wyizolowano z opium już w roku 1804 (Armie na haju)

- O 9.50 na ruinach klasztoru, o który walki trwały kilka miesięcy, zawieszono proporczyk 12. Pułku Ułanów Podolskich, bo to właśnie ta ekipa dotarła tam jako pierwsza (MC)

Lokowanie w czasie wydarzeń wydaje się niezbędne w dyskursie historycznym, stąd zapewne najwięcej tego wykładnika wśród wypisanych przez respondentów cytatów. 
Niewiele mniej cytatów, bo 18 (co stanowi 23,7\% całego korpusu dla omawianej cechy) dotyczy kolejnego wykładnika - podawanie informacji nieoficjalnych/pozapodręcznikowych, czyli takich, które wydają się trudno dostępne w oficjalnych, urzędowych dokumentach, np.

- Szef wojsk alianckich dał Andersowi aż 10 minut na podjęcie decyzji, po których nasz generał wrócił do kwatery polowej i powiedział generałowi Leese, że podejmuje się wyzwania (MC)

- tamta broń nie była tak precyzyjna jak dzisiejsza; Rodzina Rozwadowskich mialaby gablotkę z wieloma orderami (Rozwadowski)

albo które zwykle uważa się za drugorzędne w podręcznikach, jak np. autorstwo planu bitwy w kontekście jej przebiegu i rezultatu:

- kluczowa bitwa zbliżała się nieubłaganie. Naturalnie chodzi o Bitwę Warszawską. Według wielu źródeł to właśnie Tadek Rozwadowski miał przedstawić Piłsudskiemu dwa plany rozegrania bitwy, z których Wódz Naczelny wybrał ten o ataku znad Wieprza. Rozkaz wydano w nocy z 8 na 9 sierpnia, a jak wyglądało jego wykonanie i wynik bitwy?

- Oczywiście narkotyków używano też w innych kontekstach. Na przykład pewnej substancji przez jakiś czas używano w katowniach NKWD jako serum prawdy (Armie na haju)

Ten wykładnik cechy „ma wiedzę” może wynikać z uatrakcyjnienia przekazu $\mathrm{w}$ dyskursie popularnonaukowym (o zabieganiu o uwagę czytelnika zob. Maciejak 2018: 112, o atrakcyjności Maciejak 2018: 114-115; Starzec 2013: 83-84). Przytaczanie ciekawostek może przyciągnąć uwagę odbiorcy, a ich powtarzanie ją utrzymać.

Kolejnym z wykładników jest wskazywanie kontekstu wydarzeń, co pojawia się w 15 cytatach (19,7\%). W tym przypadku wyjaśnia się daną sytuację, np.

- walka [o Monte Cassino - przyp. A.B.-S.] była ekstremalnie ciężka i darowali ją sobie nawet tacy celebryci pokoju jak Hannibal czy Napoleon, którzy uznali, że mniej roboty będzie z podbiciem Włoch od północy, mimo dłuższej drogi do Rzymu. Napoleon miał nawet stwierdzić, że „Włochy to but. Trzeba wchodzić w nie od góry". Statystyki nie napawały aliantów optymizmem - Rzymu od południa nie zdobył nikt od 1400 lat (MC)

- Bo wydał rozkaz rozprawienia się z zamachowcami, ale... nie miał go kto spełnić. Poza tym sam prezydent Wojciechowski podał się do dymisji, czym zakończył przewrót majowy i być może uratował kraj przed wojną domową (Rozwadowski)

- Polityka II Rzeszy była bardzo antynarkotykowa (Armie na haju)

Pokazanie kontekstu wydarzeń umożliwia usytuowanie ich w szerszej perspektywie czasowej, często też ukazuje przyczyny opisywanej sytuacji historycznej, 
motywacje decydentów, czy pozwala ocenić dane wydarzenie. Uzasadniony wydaje się sąd, że ten wykładnik może zależeć od tematu, tj. częściej zapewne potrzebne będą tego typu wyjaśnienia w przypadku opisu bitew, rzadziej w tekstach biograficznych czy takich opartych wyłącznie na ciekawostkach (narkotyki na wojnie, alkohol w średniowieczu, historia egzorcyzmów). W tych ostatnich przypadkach historyk też ukazuje kontekst wydarzeń, ale poświęca na to zdecydowanie mniej miejsca niż np. wtedy, gdy opisuje bitwę.

O tym, że Wojciech Drewniak ma wiedzę, przesądza też posługiwanie się danymi liczbowymi. Fragmenty z tym sposobem wyrażania omawianej cechy wskazano 10 razy (13,2\%), a wśród nich np.

- Generalnie podczas całej włoskiej kampanii po stronie aliantów zginęło 312 tysięcy ludzi! Niemców jeszcze więcej - $\mathbf{4 3 5}$ tysięcy (MC)

- Naćpany nią [amfetaminą - przyp.A.B.-S.] żołnierz zdecydowanie mniej się bał, był bardziej skupiony w okopie, mógł odbywać dłuższe loty. Wiedzieli o tym alianci, bo sami Brytyjczycy pierdyknęli sobie $\mathbf{7 2}$ miliony tabletek (Armie na haju)

- bo jednym z efektów ubocznych wojny secesyjnej było prawie 400 tys. uzależnionych chłopaków (Armie na haju)

Świadczące o wiedzy (historycznej) jest też posługiwanie się nazwami wydarzeń, co pojawiło się w cytatach przytoczonych przez respondentów czterokrotnie (13\%), np.

- operacja „Husky”, która (MC)

- Bo o D-Day słyszał chyba każdy, o bitwie o Anglię zdecydowana większość... ale operacja „Husky”, która zaczęła się 10 lipca 1943 roku, jakoś nie wgryzła się tak mocno w popkulturę, mimo że była to, uwaga, NAJWIĘKSZA operacja amfibijna II wojny światowej (MC)

- Naturalnie chodzi o Bitwę Warszawską (Rozwadowski)

Wydaje się przy tym, że nie ma znaczenia, czy wydarzenia, o których mowa, są dość powszechnie znane (np. bitwa o Anglię, Bitwa Warszawska), czy też nie (operacja „Husky”). Komunikują cechę „ma dużą wiedzę” w każdym z tych przypadków.

Dziewięć odpowiedzi $(11,8 \%)$ trudno było sklasyfikować i włączono je w kategorię „inne" 25 .

Jak widać, cechę „ma dużą wiedzę historyczną” można komunikować za pomocą wymieniania dat i/lub godzin, poprzez podawanie informacji nieoficjalnych/pozapodręcznikowych, nakreślanie kontekstu wydarzeń, podawanie

${ }^{25}$ Są to np. odpowiedzi: respondent: caly tekst (MC); respondent: treść sama w sobie (MC); respondent: całokształt tekstu (Rozwadowski); respondent: zna się na historii i wykłada fakty po kolei bez zbędnych elementów (Rozwadowski); O tym możecie się dowiedzieć z poprzedniej książki (Rozwadowski). 
danych liczbowych i przywoływanie nazw wydarzeń, co zestawia tabela 6 . Dominującymi wykładnikami okazuje się wymienianie dat/godzin (26,3\% wszystkich cytatów dla cechy „ma wiedzę”) oraz przywoływanie wiadomości, mogących uchodzić za nieoficjalne (23,7\%). Nieco tylko mniejsze znaczenie ma lokowanie wydarzeń we właściwym dla nich kontekście (19,7\%). Najmniej istotne zdają się dane liczbowe $(13,2 \%)$ oraz posługiwanie się nazwami wydarzeń historycznych $(11,8 \%)$.

Tabela 6. Wykładniki komunikacyjne cechy „ma dużą wiedzę historyczną”

\begin{tabular}{|l|c|c|c|c|c|}
\hline $\begin{array}{l}\text { Wykładniki komunikacyj- } \\
\text { ne cechy „ma dużą wiedzę }\end{array}$ & $\begin{array}{c}\text { Monte } \\
\text { Cassino }\end{array}$ & $\begin{array}{c}\text { Rozwa- } \\
\text { dowski }\end{array}$ & $\begin{array}{c}\text { Armie } \\
\text { na haju }\end{array}$ & $\begin{array}{c}\mathbf{N} \\
\text { cytatów }\end{array}$ & $\begin{array}{c}\text { \% } \\
\text { cytatów }\end{array}$ \\
\hline daty i/lub godziny & 6 & 9 & 5 & 20 & 26,3 \\
\hline $\begin{array}{l}\text { informacje nieoficjalne/ } \\
\text { pozapodręcznikowe }\end{array}$ & 5 & 6 & 7 & 18 & 23,7 \\
\hline kontekst wydarzeń & 9 & 4 & 2 & 15 & 19,7 \\
\hline dane liczbowe & 6 & 0 & 4 & 10 & 13,2 \\
\hline nazwy wydarzeń & 3 & 1 & 0 & 4 & 5,3 \\
\hline inne & 4 & 3 & 2 & 9 & 11,8 \\
\hline & 33 & 23 & 20 & 76 & 100,0 \\
\hline
\end{tabular}

Źródło: opracowanie własne.

Spojrzenie na dane ilościowe pozwala wyciągnąć wniosek, że należy widoczne proporcje traktować $z$ dużym dystansem, ponieważ wskazują one, że tematyka tekstu może mieć istotne znaczenie dla nasycenia wypowiedzi konkretnymi wykładnikami. Innymi słowy, wykorzystanie i częstość użycia danego wykładnika cechy „ma wiedzę” może zależeć od tematyki tekstu. Tak na przykład, jak pokazuje tabela, daty i/lub godziny okazują się mieć największe znaczenie w przypadku tematów biograficznych (najwięcej cytatów dla tego wykładnika z rozdziału o generale Rozwadowskim), co wydaje się zrozumiałe, ponieważ w tego typu tekstach czas narracji stale się zmienia, więc wymaga ciągłego określania. Jeśli wziąć pod uwagę proporcje (zdecydowanie więcej czytających tekst o Monte Cassino), to na informacje nieoficjalne/pozapodręcznikowe zwracano uwagę szczególnie często w przypadku wypowiedzi o generale Rozwadowskim i narkotykach na wojnie - być może dlatego, że tutaj pojawiały się kontrowersyjne informacje (np. przygotowanie planu Bitwy Warszawskiej nie przez Józefa Piłsudskiego, ale generała Rozwadowskiego, dane o braniu narkotyków przez dowódców wojsk III Rzeszy), na które zwracali uwagę respondenci, a nie było takich zaskoczeń w wypowiedzi o zdobyciu Monte Cassino. Zwraca też uwagę zupełny brak danych liczbowych w tekście o generale Rozwadowskim. Zapewne tematyka biograficzna ogranicza zakres ich użycia. 
Cechę „ma wiedzę” można więc komunikować za pomocą kilku sposobów, spośród których lokowanie w czasie i podawanie informacji nieoficjalnych/pozapodręcznikowych należą do najczęstszych wykładników. Pierwszy z nich jest zrozumiały w wypowiedziach dotyczących historii, drugi przyciąga uwagę $\mathrm{w}$ dyskursie popularnonaukowym. Ciekawe, że wymieniane wydarzenia nie muszą być znane czy nieznane przeciętnemu odbiorcy, by komunikować wiedzę autora tekstu. Choć potrzebne są dane z obszerniejszego materiału, to na obecnym etapie badań uzasadniona wydaje się interpretacja, że skala użycia poszczególnych wykładników zależy od tematu wypowiedzi, który może generować częstsze użycie niektórych z nich i rzadsze innych.

Dane dotyczące cechy „ma dużą wiedzę historyczną” można zestawić z wynikami badania dotyczącymi czterech felietonistów (Krzysztof Varga, Piotr Zaremba, Szymon Hołownia, Magdalena Środa - felietony dotyczyły szeroko pojętej kultury lub kwestii społeczno-politycznych, z założenia nie operowano w nich tematyką historyczną), którym respondenci wśród wielu różnych przymiotów przypisywali cechę „znawca tematu”, analogiczną do „ma dużą wiedzę historyczną”. Obie cechy wizerunkowe wskazują na posiadanie dużej wiedzy. „Znawca tematu" komunikowany jest $\mathrm{w}$ dyskursie felietonowym za pomocą przywoływania nazw własnych (nazwisko, tytuł tekstu kultury), formułowania sądów diagnozujących/oceniających daną sytuację, przedstawiania relacji/informowania, podawania detali, osadzenia w czasie (daty), deklaracji zdobywania/szukania informacji oraz za pomocą posługiwania się wyszukanym słownictwem (Barańska-Szmitko 2018b: 196-204).

Jeśli porównać obie cechy, to „ma dużą wiedzę” wykazuje dużą zbieżność ze „znawcą tematu”. Wspólne wydają się takie wykładniki, jak osadzenie w czasie (daty), nazwy własne (u historyka występujące jako nazwy wydarzeń), dane liczbowe (detale w przypadku ,znawcy tematu”) oraz kontekst wydarzeń i informacje nieoficjalne, w których pojawia się przedstawianie relacji/informowanie. Możliwe, że analiza większego materiału wykazałaby zbieżność przywoływania kontekstu z typową dla „znawcy tematu” diagnozą (choć diagnoza zwykle dotyczyła teraźniejszości, nie przeszłości). Jedynie deklaracja zdobywania/szukania informacji oraz posługiwanie się wyszukanym słownictwem okazały się wyłączne dla „znawcy tematu”, podczas gdy pozostałe wymienione wyżej wykładniki wskazują na szeroką wiedzę autora zarówno w dyskursie felietonowym, jak i popularnonaukowym historycznym.

Warto też zestawić cechy „ma dużą wiedzę” i „pasjonat”, gdyż wydają się dosyć zbieżne $\mathrm{w}$ tym sensie, że posiadana wiedza jest dla każdej z nich niezbędna, ale jednak respondenci określili Wojciecha Drewniaka nie jednym, ale tymi dwoma różnymi przymiotami. Zestawienie wykładników obu tych cech prezentuje tabela 7.

Dane wskazują, że „pasjonat” od osoby „mającej dużą wiedzę historyczną” różni się ukazywaniem rangi/znaczenia opisywanej osoby czy wydarzeń, dialo- 
gowością widoczną w wykładniku „wyjaśniam” oraz odwoływaniem się do literatury przedmiotu. „Pasjonat” uważa zatem temat swojej wypowiedzi za ważny i to podkreśla, wchodzi w relację z odbiorcą i jako jemu bliski odsyła otwarcie do źródeł informacji (choć pamiętać należy, że prawdopodobnie odwoływanie do źródeł motywowane jest zobowiązaniami promocyjnymi).

Tabela 7. Zestawienie wykładników komunikacyjnych dla cech wizerunkowych "pasjonat” oraz „ma dużą wiedzę historyczną”

\begin{tabular}{|l|c|l|c|}
\hline $\begin{array}{c}\text { Wykładniki komunikacyjne } \\
\text { cechy „pasjonat” }\end{array}$ & $\begin{array}{c}\text { \% } \\
\text { cytatów }\end{array}$ & $\begin{array}{c}\text { Wykładniki komunikacyjne } \\
\text { cechy „ma dużą wiedzę” }\end{array}$ & $\begin{array}{c}\text { \% } \\
\text { cytatów }\end{array}$ \\
\hline $\begin{array}{l}\text { podkreślenie dużego znacze- } \\
\text { nia kogoś lub czegoś }\end{array}$ & 39,3 & daty i/lub godziny & 26,3 \\
\hline $\begin{array}{l}\text { szczegóły historyczne (też } \\
\text { pozapodręcznikowe) }\end{array}$ & 29,5 & $\begin{array}{l}\text { informacje nieoficjalne } \\
\text { (pozapodręcznikowe) }\end{array}$ & 23,7 \\
\hline wyjaśniam & 13,1 & kontekst wydarzeń & 19,7 \\
\hline $\begin{array}{l}\text { odwoływanie do literatury } \\
\text { przedmiotu }\end{array}$ & 11,5 & dane liczbowe & 13,2 \\
\hline inne & 6,6 & nazwy wydarzeń & 5,3 \\
\hline & & inne & 11,8 \\
\hline razem & $\mathbf{1 0 0 , 0}$ & razem & $\mathbf{1 0 0 , 0}$ \\
\hline
\end{tabular}

Źródło: opracowanie własne.

Szczegóły natomiast wydają się wykładnikiem zarówno „pasjonata”, jak i osoby „mającej dużą wiedzę”, jeśli bowiem przyjrzeć się korpusom cytatów obu cech, to fragmenty, w których aktualizuje się cecha „pasjonat” za pomocą użycia szczególów, są fragmentami zawierającymi daty i/lub godziny, kontekst wydarzeń, nazwy własne, dane liczbowe i nieoficjalne informacje, czyli wszystkie wykładniki cechy „ma dużą wiedzę historyczną”. Najwyraźniej takie szczegóły mogą komunikować obie te cechy. Dostępny materiał nie pozwala określić warunków, w których te wykładniki służą komunikowaniu jednej bądź drugiej cechy. Być może umożliwi to dostępność obszerniejszego materiału. Możliwe też, że posługiwanie się szczegółami historycznymi jest wykładnikiem polifunkcjonalnym wizerunkowo, tj. służy komunikowaniu obu wspomnianych cech bez względu na warunki komunikacji (np. temat, płeć autora, medium etc.). Zaznaczyć przy tym należy, że wykładniki dla cechy „ma dużą wiedzę” to rozwiązania dyskursowe konieczne do prowadzenia narracji historycznej i choć wykazują zbieżności z przypisywaną felietonistom cechą „znawca tematu”, to są przede wszystkim typowe dla historycznego wywodu (daty, kontekst wydarzeń, dane liczbowe, nazwy wydarzeń). 


\subsubsection{Podsumowanie i wnioski}

Warto pamiętać, iż wszystkie interpretacje tego rozdziału należy traktować $\mathrm{z}$ pewnym dystansem ze względu na niewielką, spowodowaną utrudnieniami pandemii, liczbę analizowanych tu ankiet. Poniższe uwagi są więc raczej wyrazem pewnych tendencji niż miarodajnie potwierdzonymi wnioskami.

Pierwsza część badania pozwoliła określić poszczególne cechy wizerunkowe Wojciecha Drewniaka. Pozytywnie zweryfikowano hipotezę, iż w wizerunku książkowym (na podstawie tekstów) dominują cechy dotyczące wiedzy prowadzącego (np. „ma dużą wiedzę”), poczucia humoru („zabawny”) i komunikatywności („komunikatywny”), choć najczęściej uznawano, że historyk jest „bezpośredni”. Zaznaczyć jednak należy, że te przymioty nie są równoważne, ale widać silny prymat cech dotyczących zdecydowanej postawy autora oraz przystępności i atrakcyjności przekazu. Nieco mniejsze znaczenie ma oryginalność i humor oraz wiedza i bycie „na czasie” tego pasjonata i patrioty.

Oprócz zdecydowanej postawy (która zapewne wynika $\mathrm{z}$ wyrazistego wartościowania stosowanego w tekstach historyka) oraz cech dotyczących wiedzy, ważny dla wizerunku autora wydaje się styl jego wypowiedzi (zob. cechy wizerunkowe niezwiązane ze stanowczą postawą i wiedzą). Najwyraźniej oryginalność tego stylu zwraca szczególną uwagę czytelników i być może wynika z różnicy między znanym z podręczników dyskursem historycznym a jego popularnym wydaniem - im bardziej wypowiedzi Wojciecha Drewniaka różnią się od znanego ze szkoły sposobu mówienia o historii, tym bardziej zwracają uwagę i stanowią podstawę przypisania mu określonych cech wizerunkowych.

Zebranie korpusu cytatów dotyczących cech wizerunkowych „pasjonat” oraz „ma dużą wiedzę historyczną” umożliwiło wyłonienie wykładników komunikacyjnych typowych dla wspomnianych cech. Ich analiza wykazała, że „pasjonat" oparty jest na (zwykle pozytywnym) wartościowaniu - podkreślaniu znaczenia opisywanych osób czy zjawisk, podczas gdy „ma dużą wiedzę historyczną” komunikowany jest przede wszystkim za pomocą przywoływania dat i informacji nieoficjalnych/pozapodręcznikowych. Tym samym pozytywnie zweryfikowano hipotezę dotyczącą cechy „pasjonat” (zakładano, że jej komunikowanie oparte jest na zaangażowaniu i szukaniu informacji), ponieważ zaangażowanie wyraża się poprzez podkreślenie ważności podejmowanego tematu (najliczniej reprezentowany wykładnik), szukanie informacji w podawaniu szczególów (drugi z najliczniejszych wykładników) i odnoszenie do literatury przedmiotu.

Choć „ma dużą wiedzę” ma wykładniki typowe dla narracji historycznej, to - tak jak się spodziewano - są to wykładniki analogiczne do cechy „znawca tematu" (cecha wyłoniona i opracowana w innych, obszernych badaniach), tj. wszystkie wykładniki oprócz deklaracji szukania informacji i wyszukanego słownictwa wykazują zbieżność, co może świadczyć o tym, że cecha historyka „ma dużą wiedzę" jest (właściwą autonomicznie funkcjonującemu popularnonaukowemu 
dyskursowi historycznemu) odmianą dyskursową „znawcy tematu”. Wbrew założeniom elementy informowania/relacjonowania (wykładnik „znawcy tematu”) nie są na tyle immanentne dla wywodu historycznego, by nie zostały zauważone. Wydaje się, że relacjonowanie/informowanie realizuje się w takich wykładnikach cechy „ma dużą wiedzę” jak usytuowanie w kontekście i podawanie nieoficjalnych informacji, choć nie są to dominujące sposoby komunikowania wiedzy historyka. Zaznaczyć przy tym należy, że powyższe zbieżności funkcjonują na zasadzie analogii, a nie na pełnej tożsamości wykładników i szczegółowe relacje między wykładnikami komunikującymi wiedzę w różnych dyskursach pozostają do określenia w obszerniejszej wersji badania.

Przeprowadzona analiza pozwoliła także określić relację między „pasjonatem” a osobą „mającą dużą wiedzę”. Podawanie szczegółowych informacji jest dla tych dwóch cech wizerunkowych wspólne, ale pasjonat oprócz tego często wartościuje (zwykle pozytywnie) obiekty, które opisuje (osoby, zjawiska, zdarzenia). Główne wykładniki cechy „ma wiedzę” wydają się pochodną dyskursu historycznego $\mathrm{w}$ jego popularyzatorskim wydaniu.

Jak zatem widać, wizerunek historyka popularyzującego wiedzę historyczną w przypadku Wojciecha Drewniaka oparty jest na zdecydowanej postawie autora książek iyoutubera. Dla komunikowania cechy „pasjonat” kluczowe wśród wykładników staje się podkreślanie ważności podejmowanych tematów i ich aspektów, podczas gdy dla komunikowania wiedzy („ma dużą wiedzę historyczną”) podawanie różnego rodzaju dat i szczegółów historycznych. Ponadto komunikowanie wiedzy w dyskursie historycznym, choć nie identycznie, to odbywa się w dużej mierze analogicznie do komunikowania wiedzy w dyskursie felietonowym dotyczącym kultury lub kwestii społeczno-politycznych. Dalsze badania na większym materiale pozwolą zweryfikować widoczne w tej próbce badawczej tendencje i lepiej określić zarysowane w pozyskanych do tej pory danych wzajemne relacje.

\section{Literatura}

Adamczyk Karolina (2016), Opinie o prezydencie Rafale Dutkiewiczu wśród wroctawian $i$ internautów w kwietniu 2015 r., [w:] Badanie i projektowanie komunikacji 5, red. A. Siemes, M. Grech, M. Wszołek, Libron, Wrocław, s. 119-145.

Barańska-Szmitko Anna (2018a), Wptyw stowa i obrazu na wizerunek osoby publicznej, Wydawnictwo Uniwersytetu Łódzkiego, Łódź.

Barańska-Szmitko Anna (2018b), Wizerunek felietonisty i sposoby jego werbalnego komunikowania, Wydawnictwo Uniwersytetu Łódzkiego, Łódź.

Barańska-Szmitko Anna (2020a), Czy przystępna wypowiedź eksperta umniejsza jego autorytet? Wizerunek Wojtka Drewniaka na podstawie wypowiedzi umieszczanych na kanale YouTube "Historia bez Cenzury”, [w:] Badanie komunikacji/projektowanie komunikacji 3, red. M. Grech, K. Lachowska, K. Olender, A. Siemes, Libron, Wrocław, s. 179-195. 
Barańska-Szmitko Anna (2020b), Relacja między dyskursem popularnonaukowym w serwisie YouTube a wizerunkiem vlogera na przykładzie prowadzacych kanały "Historia Bez Cenzury” oraz „Irytujacy Historyk”, „Studia de Cultura. Annales Universitatis Paedagogicae Cracoviensis", t. 12 (2), s. 62-77.

Brodnicka Maja (2019), Wizerunek prasowy Jarosława Kaczyńskiego w wybranych tygodnikach opinii podczas polskiej kampanii parlamentarnej w 2015 r., „Łódzkie Studia Teologiczne”, nr 28, s. 21-43.

Fleischer Michael (2007), Ogólna teoria komunikacji, Wydawnictwo Uniwersytetu Wrocławskiego, Wrocław.

Fleischer Michael (2008), Konstrukcja rzeczywistości 2, Oficyna Wydawnicza Atut, Wrocław.

Fleischer Michael (2012), Typologia komunikacji, Primum Verbum, Łódź.

Gierło-Klimaszewska Katarzyna, Gajda Joanna (2019), The image of Prime Ministers Ewa Kopacz, Beata Szydto and Donald Tusk in the Czech Portal iDnes, „Państwo i Społeczeństwo", nr 2 (XIX), s. 129-149.

Gronkowska Agnieszka (2018), Media społecznościowe jako narzędzie nowej ewangelizacji na przykładzie twórczości internetowej Adama Szustaka OP, „Roczniki Pedagogiczne", nr 10(46), s. 113-128.

Kosman Marcin (2019), Kto jest kim w kondominium? Chwyty perswazyjne i narzędzia retoryczne Grzegorza Brauna, „Społeczeństwo. Edukacja. Język”, nr 9, s. 47-52.

Lewandowska Maria (2018), YouTube jako narzędzie kreowania wizerunku na przykładzie wideobloga Kammel Czanel, „Media - Kultura - Komunikacja Społeczna”, nr 14, s. 35-50.

Maciejak Katarzyna (2018), Youtube w edukacji. Strategie nadawcze wideoblogerów, Universitas, Kraków.

Maciołek Marcin (2117), Promieniowanie K (komputerowe), czyli o oddziaływaniu rzeczywistości informatycznej na polszczyznę, „Postscriptum Polonistyczne”, nr 1 (19), s. 197-211.

Mazurkiewicz Barbara Maria (2008), Wizerunek Leonida Kuczmy na łamach tygodnika „Wprost”, w latach 1994-2004, „Studia Medioznawcze”, nr 3 (34), s. 11-44.

Nobis Iwona (2019), Internet pseudonyms of Polish YouTubers. Their origin, structure and place in the modern anthroponymy system, „Annales Universitatis Mariae Curie-Sklodowska, sectio FF - Philologia”, nr 2 (37), s. 97-107.

Secler Bartłomiej (2013), Ksiądz Józef Tischner jako osobowość medialna, „Studia Medioznawcze", nr 4 (55), s. 113-130.

Starzec Anna (2013), Styl popularnonaukowy - styl dyskursu popularnonaukowego, [w:] Style współczesnej polszczyzny. Przewodnik po stylistyce polskiej, red. E. Malinowska, J. Nocoń, U. Żydek-Bednarczuk, Universitas, Kraków, s. 71-110.

Stasiołek Ilona (2012), Językowy obraz zmagań pisarskich Teodora Parnickiego na podstawie „Dzienników z lat osiemdziesiątych”, „Język w Komunikacji”, nr 2, s. 111-117.

Stefan Anna (2019), Wplyw wypowiedzi polskich youtuberów na ksztaltowanie się kompetencji językowej u dzieci - zarys problematyki, „Logopaedica Lodziensia”, nr 3, s. 163-173.

Szymański Adam (2013), Wizerunek Steve'a Jobsa, Communication Design Magazine, Vol. 5-6, http://www.cd-magazine.uni.wroc.pl/artykul/wizerunek_steve_jobs/ [dostęp: 15.04.2020]. 
Wójcik Agnieszka (2019), Językowe i pozajęzykowe mechanizmy ksztattowania pamięci zbiorowej w popularnonaukowym programie "Historia bez Cenzury”, „Stylistyka”, nr XXVIII, s. 247-264.

Zatorska Agnieszka (2016), Przydatność analizy semantycznej i składniowej do badań nad tekstem. Wybrane tytuły w stoweńskich tekstach popularnonaukowych, „Studia z Filologii Polskiej i Słowiańskiej”, nr 51, s. 238-250.

\section{Materiał analityczny}

Drewniak Wojciech (2017), To on - typ pokorny - Tadeusz Rozwadowski, [w:] tegoż, Historia Bez Cenzury 2. Polskie koksy, HBC, Kraków, s. 181-204.

Drewniak Wojciech (2018), Niemożliwe? Dajcie to Polakom! - bitwa o Monte Cassino, [w: ] tegoż, Historia Bez Cenzury 3. Poland first to fight... czyli II wojna światowa, HBC, Kraków, s. 219-241.

Tekst filmu „Armie na haju”, opublikowanego 19.09.2019 na kanale Historia Bez Cenzury, https://www.youtube.com/watch?v=LLdtObjRHrA\&t=3s\&has_verified $=1$ [dostęp: 1.06.2020]. 